\title{
MARKETING AND PRICING LEGISLATION
}

\author{
HOWARD R. WARD*
}

\begin{abstract}
This article deals with a consideration of the legislation which has been introduced throughout the past year relating to the marketing and pricing of petroleum and petroleum products in both the provincial and federal spheres. The author deals with the main provisions of each of the provincial and federal Bills concerning marketing and pricing followed by reference to some of the inherent problems of the legislation and a short study of the effects such provisions have had or may have on petroleum lawyers.
\end{abstract}

\section{INTRODUCTION}

This discussion will centre on legislation which has been introduced throughout the past year relating to the marketing and pricing of petroleum and petroleum products in both the provincial and federal spheres. Through the introduction of such legislation, Government was attempting to guarantee for itself a greater share of the increasing returns received from petroleum sales as well as to provide means whereby the Canadian market, or portions thereof, would be ensured an ample supply of petroleum products in future years. While part of this legislation has achieved statute form, the remainder has either not yet been passed or is still awaiting proclamation. Apart from the legislative success of the various bills, the petroleum industry has exhibited a general concern merely over the introduction of such legislation.

I propose to deal first with the various provincial bills and statutes and then briefly with those introduced in Ottawa. An outline of the main provisions of each bill concerning marketing and pricing shall be presented and followed by reference to some of the inherent problems of the legislation. A short study shall also be made of the effects such provisions have had, or may ultimately have, on the day to day involvements of the petroleum lawyer.

\section{BRITISH COLUMBIA}

In British Columbia the major statute affecting the petroleum industry is the Energy Act, which was first introduced as Bill 148 early in 1973. Royal assent was given to the Act in its present form on April 18, 1973. Part IV of the Act, which is entitled "Regulation of the Petroleum Industry", has not been proclaimed; and it may be replaced by the provisions of Bill 18, The Energy Amendment Act, which received its First Reading on April 24, 1974.

After the Energy Act was first introduced, many sectors of industry voiced strong disapproval, but this was particularly true of the petroleum industry. The main objections made by the petroleum industry concerned Part IV of the Act.

Within Part IV, s. 74 contained the provisions relating to the fixing of prices of petroleum products. Pursuant to this Section, the British Columbia Energy Commission, which was constituted under the Act, would have the power to fix maximum and minimum and wholesale and retail prices of petroleum products, and to fix price differentials applicable in different parts of the province, both for wholesalers and retailers. Section 75 provided for amendment to any

\footnotetext{
- Solicitor, Gulf Oil Canada Limited, Calgary, Alberta.
} 
existing contract to the extent necessary that such contract conform to the price changes directed pursuant to s. 74 .

Submissions from various companies were made to the Commission, and the severe criticism of Part IV eventually led to the introduction of Bill 18. This Bill does not contain radical amendments, but merely modifies the provisions of Part IV so as to simplify the administrative duties of the Commission. The Bill revises the provisions concerning prices to the effect that, "no Seller shall increase its prices without the approval of the Commission'. The Commission is also given the power to review any price increase occurring up to 6 months prior to the Bill coming into force, and to order a reduction in price if that is deemed necessary. There has been little change to the former Section 76 which dealt with contracts.

The Energy Act also contains, in Part II, provisions in relation to energy resources. Although Part II contains only two sections, they are worded so as to give the Commission extremely wide powers of regulation with respect to the petroleum industry. Further, because British Columbia has no Conservation Act, and as there has not yet been a proclamation respecting Part IV, the Commission must presently effect all control and regulation over the industry through the powers granted by Part II. For instance, the Commission has used its powers under Subsection (e) of Section 19 in requesting information relating to pricing from the industry. Moreover, it is apparently prepared to utilize these powers further through the introduction of price regulation. Subsection (b) of Section 19 directs the Commission to advise the Lieutenant Governor in Council of whatever measures it considers necessary to promote discovery, conservation, and prudent use of energy resources. It was undoubtedly pursuant to this directive that the Commission recommended the introduction of the British Columbia Petroleum Corporation Act.

A basic problem in the Energy Act is that the definition of "energy utility" is both imprecise and ambiguous, and, therefore, leaves considerable doubt as to the application of several provisions of the Act. Another problem arises with the definition of "petroleum products". It is noted that "petroleum" is included in a definition that otherwise relates to refined or processed products, which would indicate that the Commission has been given the power to regulate and control the price of crude oil in the Province. However, as the supply, or the purchase and sale of "crude oil" is not included in the definition of the term "petroleum industry", such operations apparently are not subject to regulation or control by the Commission.

The Act was designed with the intent that those businesses engaged in providing the public with light, heat and power, and generally recognized as true public utilities, are to be regulated under Part III of the Act; whereas the "petroleum industry", which is defined to include refining of petroleum, storage of petroleum and "petroleum products" and the distribution and sale of "petroleum products", is to be regulated under Part IV of the Act. Many of the companies engaged in the "petroleum industry" in British Columbia are also engaged, to some degree, in the business of owning or operating equipment or facilities for the production, generation, storage, transmission, sale, delivery or furnishing of gas (past the wellhead) and petroleum (past the wellhead) for the production of heat or power. It is, therefore, quite possible that such companies could be regulated separately under both Parts III and IV of the Act. On the other hand, by virtue of the words "not otherwise an energy utility", appearing in subsection (iii) of the definition of "energy utility", such companies might well be regulated only as an energy utility under Part III - particularly if "gas" means something other than natural gas, and if the meaning of the words "any other agency" includes "petroleum products". 
The main effect on existing documentation in B.C. is a result of the constition of the Petroleum Corporation. Although this Corporation is established by Special Act, the recommendation of the Commission likely led to the introduction of the Petroleum Corporation Act.

Under Section 5 of the Petroleum Corporation Act, the Corporation has power to buy, sell and deal in petroleum and natural gas. Pursuant to this provision, the Petroleum Corporation entered into an arrangement with Westcoast Transmission Company Limited, the major purchaser, carrier and processor of natural gas in the province, whereby the Petroleum Corporation was to buy all of the natural gas purchased by Westcoast, under current Gas Purchase Contracts, at a price equal to Westcoast's cost, plus a rate of return of $91 / 2$ percent on invested capital and operating costs.

The Petroleum Corporation then contacted all producers contracting with Westcoast and gave them the choice of either continuing with the current Gas Purchase Contract and paying royalty to the Crown, or of accepting prices of approximately 18.5 cents per mcf for "old gas" and up to 22.5 cents per mcf for "new gas" (gas put on stream since November 1973), subject to the stipulations that there would be no price redetermination clause, no favoured nations clause and no royalty payable to the Crown.

Since it was obvious that, if a choice was made to continue under the current Gas Purchase Contracts, the Crown Royalty would be increased substantially, most, if not all, producers chose to accept the proposal offered by the Petroleum Corporation. Under this proposal, the price appeared fair due to the fact that no royalty was payable, and that Westcoast paid all gathering and processing charges.

Clearly, by virtue of these alterations, the Petroleum Corporation Act has had a great effect on current Gas Purchase Contracts. In addition, as the Lessee would no longer be paying royalty, the arrangement made with the Petroleum Corporation would also change the intent of the Crown Leases granting natural gas rights. The Gas Purchase Contracts were amended by means of Novation Agreements whereby the Petroleum Corporation joined as a party. However, no amendments were made to Crown Leases. The Novation Agreements contained a provision whereby the Petroleum Corporation undertook to pay the current royalty under the Leases. A question arises as to the position of the producer if such payment is not made. Amendment, therefore, should also be made either to the Leases, or to Part XI of the Petroleum and Natural Gas Act, respecting royalty, requiring the Petroleum Corporation to pay the royalty. Thus the Lessee and his rights under the Lease would be protected from any default in royalty payment on the part of the Petroleum Corporation.

Amendment is necessary not only to protect the Lessee's interest under the Leases, but also to protect him from any liability which might arise under various agreements containing covenants to keep the Lease in good standing. As well, would any question of liability evolve from the Lessee accepting the offer from the Petroleum Corporation rather than maintaining the Gas Purchase Contract complete with the right to price redetermination?

In the past, numerous overriding royalty agreements have been worded in a fashion that directed that calculation of royalty be analogous to the method of calculation of Crown Royalty. If Crown Royalty is no longer payable, is royalty still payable under the overriding royalty agreement?

\section{ALBERTA}

Singularly, Alberta has the most comprehensive marketing legislation in the country. The approach taken by the Petroleum Marketing Act is unique, if not 
extreme, and, therefore, its provisions warrant more attention than those contained in any other piece of legislation.

Section 13 of the Act outlines the general powers of the Petroleum Marketing Commission established pursuant to the Act. These powers give the Commission the right to act in a manner which could affect most types of documentation currently in use in the petroleum industry. Section 15 directs the Commission to accept delivery of the Crown's share of the petroleum in kind, and to sell such petroleum within the Province "at a price that is in the public interest of Alberta". Section 16 authorizes the Commission to direct a pipeline operator to carry, and an owner of a storage facility to store the petroleum received, in accordance with Section 15. If mutual agreement cannot be reached on the fees respecting such services, provision is made for the Public Utilities Board to establish such charges. Section 21 directs the Commission to sell the Lessee's share of petroleum "at the highest price that it may reasonably negotiate having regard to the market conditions prevailing at the time of the sale". Section 24 allows the Lieutenant Governor in Council to make "regulations for the establishment of a scheme or plan for the orderly and equitable marketing of all petroleum produced in Alberta".

Prior to assessing the effect this legislation may have on various existing contracts, I would like to point out a few ambiguities and areas of concern within the Act:

(a) The Commission is given wide powers to deal with "petroleum" in Alberta. However, "petroleum" is undefined, and it is not clear whether condensates are included.

(b) The Act directs the Commission to accept delivery of the Crown's royalty share of the petroleum, while the obligation on the part of a Lessee "to deliver the petroleum" is set out in the Mines and Minerals Amendment Act. Unless delivery is accepted at the wellhead, how are the various gathering, transportation and storage costs, relating to the royalty portion of the petroleum, to be covered? Similarly, provision is made whereby the Commission shall sell the Lessee's share of the petroleum, but again, no mention is made of transportation and storage costs.

(c) Since the right to collect royalty is given to the Commission, the usual set-off, in the form of drilling incentives, allowed to be made against royalty payments when administered by the Department of Mines and Minerals, is no longer available. Apparently, such credits can only be applied toward rental and purchases at Crown Sales.

(d) Should the situation in which petroleum is taken by the Commission from a producer and is subsequently re-sold to the same producer be considered a "sale", the federal tax position of many companies could be affected. Formerly, a tax advantage was enjoyed in relation to unrealized profits arising from valuation of inventory in computing income under Section 10 of The Income Tax Act, where companies, particularly integrated companies, could value inventory at cost ("wellhead cost"), rather than market value. If the position is that an actual sale by the Commission takes place, such tax relief could disappear.

(e) Another matter usually covered in most documentation concerns products used at the wellsite in connection with production activities. No mention of this point is made in the Act.

(f) There is also a problem in the difference of the obligations of the Commission respecting the sale of the Crown's share of petroleum and the Lessee's share. As noted previously, the Commission is to sell the Crown's share "at a price that is in the public interest of Alberta", and the Leesee's share "at 
the highest price that it may reasonably negotiate having regard to market conditions prevailing at the time of sale." Under varying market conditions the Lessee could well receive a different price for his share than that received by the Commission for the Crown's share.

(g) Section 24 gives the Lieutenant Governor in Council the power "to make regulations for the establishment of a scheme or plan for the orderly and equitable marketing of all petroleum products in Alberta". This provision has sufficient scope to include freehold production, although the Act does not expressly refer to this intention.

Most companies are uncertain as to how the Marketing Commission will operate or what changes may occur in the present structuring, involvements and responsibilities of producing and purchasing companies. At present, producers have submitted various informational forms to the Commission, but apart from this no changes have yet been made to the existing system for crude oil purchase, sale and distribution. Notwithstanding that the Act may have been introduced merely to strengthen the position of the Alberta Government vis-a-vis the national scene, the fact is that the Government has established the Marketing Commission, and, therefore, we must assume that the provisions of the Act will be carried out in accordance with their expressed written intent.

The following study on the effects of the legislation on various documentation is based on that assumption:

(a) Operating Procedure - Clauses in such agreements concerning Ownership and Disposition of Production will become ineffective and meaningless. As well, the operator's right to a lien, on a non-operator's share of production for non-payment of its share of cost and expenses, may be lost. This comment applies equally to production penalty payments when independent operations result in production. Pursuant to Section 21, the Commission can both sell on behalf of each Lessee and return all sales proceeds back to each Lessee, hence the Independent Operator will be unable to get more than his share of the production, unless he can register some sort of garnishee or lien with the Commission against the non-operator's share of production. In the event the Commission elects to pay the operator directly, many of these problems would be resolved; however, they would be replaced with others. For example, most operating procedures provide for payment, to the non-operators, of their share of the proceeds from the sale of a given month's production, on or before the 25th day of the month next following. Pursuant to Section 21 (d) of the Act, the Commission is required to make payment to the Lessee "within 60 days after the sale of the petroleum". Accordingly, if an operator is to comply with the provisions of the operating procedure, he must make payment out of his own operating revenue, or, alternatively, seek amendment to the operating procedure.

In the past, the general attitude of the right to take in kind by each participant, gave some credence to the claim that the parties to an Operating Agreement were not in partnership. This application was particularly important to those companies, subject to United States taxation, which elected for exclusion from the application of Subchapter K, Chapter I, Subtitle A, of the United States Internal Revenue Code. The fact that the right to take in kind will not be enforceable, diminishes any credibility such argument previously enjoyed.

A further area of consideration relates to the Commission's position on insurance. Does the Commission have an insurable interest in respect to all production in Alberta? It is surely advisable that if the Commission is agent for the producer and therefore stands temporarily in the position of bailee, the 
Commission be required to carry insurance to cover all parties for loss of petroleum, or, at least, to indemnify all parties against such loss.

(b) Pooling Agreements, Unit and Unit Operating Agreements - Many of the points mentioned in reference to operating procedures apply as well to pooling and unit agreements. However, additional problems will occur if the Commission does not involve itself with freehold production. If freehold production constitutes only a small portion of the total production, transportation and sales costs which separately deal with that production will be rather high.

(c) Freehold Petroleum and Natural Gas Lease - If the Commission elects to handle Freehold as well as Crown production, a few problems may arise for the Freehold Lessee. In most leases the Lessee covenants to make royalty payments on or before the 25th day of the month next following the month in which the petroleum was produced. It may be rather difficult to convince a Lessor that the Lease should be amended because payments will be a month later than currently required by the lease. As well, some leases state that payment shall be " $121 / 2 \%$ of the current market value of the substances produced". Does the term "current market value" correspond to "the highest price that the Commission may reasonably negotiate"?

(d) Overriding Royalty Agreements - Many Overriding Royalty Agreements as well as Freehold Leases reserve a gross royalty of "x\% of the current market value computed at the wellhead of all petroleum substances produced from the lands". Therefore, whether the Commission or the producer markets the substances, the current market value supposedly will be the total price received for the product including increased Crown royalty and Federal export taxes. Payment of such an override could accordingly involve a much larger portion of the Lessee's share of production than contemplated at the time the Agreement was executed. One method of avoiding this problem in the future would be to restrict reservations of interest to net profits or carried interests. It would appear that the granting of any form of gross royalty interest is not advisable unless the gross is calculated in relation to some figure other than the current market value.

As with other agreements, the time of payment will also be a problem with Overriding Royalty Agreements.

Further, some Overriding Royalty Agreements allow the royalty holder to take his share of production in kind. This provision will not be enforceable.

(e) Storage Agreements, Battery and Commingling Agreements, Fieldgate Agreements - These Agreements will be affected radically if the Commission chooses to use its power to move products through existing pipelines or store products in existing facilities. Commingling Agreements will be meaningless since all products will be marketed by the Commission. By Section 2l(f), the Commission may not discriminate as between owners or between petroleum from different pools. An acute problem may develop in the event the Commission decides not to market freehold production but rather to use those facilities formerly utilized for the handling of freehold production to handle Crown production.

It appears inevitable that the Commission will be joined as a party to many of the afore-mentioned agreements.

(f) Agreements respecting Crude Oil e.g. (1) Trade (2) Sales (3) Supply Operations under these agreements will be changed almost entirely. If a trade agreement exists whereby $\mathrm{X}$ producer supplies $\mathrm{Y}$ producer with Alberta crude in return for $\mathrm{Y}$ producer supplying $\mathrm{X}$ producer with Saskatchewan crude, $\mathrm{X}$ will no longer be able to fulfill his obligations of supply and hence may well lose his 
supply from $\mathrm{Y}$ in Saskatchewan. Sales Agreements will be inoperable since the Commission will be doing all the selling and buyers will probably prefer to buy direct from the Commission rather than through a Third Party.

The subject of pricing has, for the most part, not been attacked in Alberta as directly as in other jurisdictions. For example, The Alberta Arbitration Amendment Act, which was introduced in late 1973 as Bill No. 53, greatly affected pricing even though it could not be classified as a price regulating statute within the usual meaning of the phrase. In the past few years several applications for gas export permits were made to the Energy Resources Conservation Board, approved by the Board and forwarded to the Cabinet to be issued as Orders in Council. Cabinet approval was not forthcoming, probably because the Cabinet was of the opinion that the price of the gas to be exported was too low. Instead of approving the applications the Cabinet introduced The Arbitration Amendment Act requiring that in any arbitration respecting the redetermination of the price of gas sold under a gas purchase contract, the arbitrators shall determine the field value in fixing the redetermined price. (The term "field value" is defined in reference to the commodity value of gas.) By enacting this legislation, the government seemed to be suggesting that no export permits would be approved unless the price paid for the gas reflected its commodity value. In any event, the Act has certainly had an enormous effect on the pricing of natural gas as exemplified by the recent Gulf-TransCanada Arbitration and the many settlements directly attributable to that award.

After introducing forces into the market which would necessarily result in higher natural gas prices, the Government introduced legislation to protect the Alberta consumer from these prices. Under the provisions of Bill 54, The Natural Gas Rebates Act, the Minister may make rebates to vendors, suppliers, intermediate purchasers or eligible consumers in respect of natural gas purchased or delivered for consumption or use within Alberta. Due to the fact that this legislation was introduced very recently, the mechanics of the rebate system are yet untested and many of the consequences of the legislation are still unknown.

The fixing of prices for the sale of propane and butane in Alberta has recently been provided for through The Gas Utilities Amendment Act which brings propane and butane under the provisions of The Gas Utilities Act. Pursuant to section 6.1, introduced by the Amendment Act, the Public Utilities Board fixed the price of propane and butane to be sold in Alberta effective March 6, 1974. Because of this, no change in charges for propane, butane or connected services may be made without the approval of the Public Utilities Board under section 35 . The freezing of such prices is liable to cause extreme problems to the industry, especially to those companies in the refining business. At times, refineries have an excess of propane or butane. In order to make storage space available, refiners are anxious to sell such surpluses at whatever price they can get. If refiners are unable to sell at such reduced prices, they must continue to tie up needed storage space and wait for a buyer who is willing to pay the set price for the surpluses. Conversely, at other times refiners have extreme shortages of feedstock to be used in the refining process and are therefore willing to pay "top dollar" in order to obtain a supply. With prices for such feedstock set by the Board, those in the above mentioned position have no bargaining tool to obtain the needed supply. This may result in a slowdown of the refining process and a shortage of refined products can be expected which might necessarily result in breach of supply contracts.

\section{SASKATCHEWAN}

The Oil and Gas Conservation, Stabilization and Development Act, which was introduced as Bill 42 and received Royal Assent on December 19, 1973, 
provided for the fixing of the price of crude oil. Within Part III, which has not yet been proclaimed, provision is made for the regulation of wholesale and retail prices of refined petroleum products. The Act sets out the basic well-head price of a barrel of oil and imposes a tax equal to the difference between the basic well-head price and the actual well-head price received. In fact, by section $4 \mathrm{a}$ in Bill 128 amending the Act, the Minister is allowed, in the event oil is sold for less than the well-head price, to establish the price at which any particular grade of oil should have been sold and require the tax to be calculated accordingly. Section 8 provides that the Minister may require a producer to deduct and pay the tax from another owner's share of the production.

Since Boyd Lowery has outlined in detail many problems arising from the Act and as I have already paid considerable attention to the effects of Alberta legislation on documentation (some comments of which are relevant in Saskatchewan as well), I will only make one comment on the effect of the Saskatchewan Act that perhaps is more relevant in Saskatchewan than in other jurisdictions. Generally, most documents include a clause which reads similar to the following: "This agreement shall be subject to all the laws, orders and regulations of any governmental authority having jurisdiction herein". The question is, what relevance does this clause have to the fiduciary duty which is assumed by operators and other parties to various agreements? Is it the duty of such person not to make payments on behalf of the other parties until he is sure the taxing authority has jurisdiction to levy the impost? Further, if he makes payments and the legislation is then proven to be ultra vires the jurisdiction of the Province, do the various non-operators have an action against the operator to recover the moneys paid to the government? If such an action would lie, an operator would be in rather an unfortunate position being unable to collect the moneys from the Crown due to the Proceedings Against The Crown Act.

\section{FEDERAL}

There have been three pieces of legislation introduced during the 29th Parliament which relate to the pricing and marketing of petroleum products.

The first statute is the Energy Supplies Emergency Act which was introduced by the Minister of Energy, Mines and Resources on December 3, 1973 as Bill C-236 and received its Third Reading January 11, 1974.

The Act establishes the Energy Supplies Allocation Board. Following the declaration by the Governor in Council of a national emergency, the Board shall, under the authority of Part I, prepare mandatory allocation programs concerning petroleum related products, alternative fuels and electric power. Such programs shall designate specific regions of Canada in which a program will operate, specify the products controlled, outline priorities for use of the product and provide for systematic allocation of supplies of the product.

Under Part II, the Governor in Council may order rationing of products controlled by the program. Under Part III, provision is made for the modification of contracts to enable compliance with the Act.

The first point to be stressed is that the provisions of this Act will not be used unless a national emergency is declared. In fact, the Act may well be superfluous to the general powers relating to peace, order and good government granted to the Federal Government in the preamble of Section 91 of the BNA Act. If such a situation existed, perhaps those matters considered as priorities today would not then achieve similar importance. Nevertheless, viewing the provisions of the Statute with our current ideas and concerns in mind, there are a few things to be noted. 
The Act gives the power to allocate and ration petroleum products in order to assure sufficient supply of products in the various parts of Canada. Besides granting the right to allocate and ration petroleum products, the Act also gives the right to make regulations providing guidelines for price, quality and quantity provisions in contracts, to prescribe prices for controlled products within particular areas and to prescribe credit terms or payment schedules for wholesale customers.

Although many of the provisions of the Act could have an extreme effect on existing contracts, it is assumed that the force majeure clause found in most contracts would restrict any liability which might arise. If these clauses, appearing in current contracts, are not wide enough to cover the application of this Act, perhaps amendments should be made.

Bill C-245, the Oil Export Tax Act, was introduced by the Minister of Finance on December 14, 1973. It received Third Reading on January 7, 1974, after incorporation of amendments recommended by the Committee.

The Act provides for the imposition of a tax on each barrel of crude oil exported from Canada with different tax rates for each time period up to, but ending with, $\$ 6.40$ per barrel for the period February 1, 1974-April 1, 1974. There is also provision made for the Minister to pay $50 \%$ of the tax revenue to the Province in which the exported oil was produced.

As mentioned in reference to Alberta legislation, this Act will pose certain problems in relation to Gross Overriding Royalties and Freehold Leases in the event royalty is payable on current market value (which value is deemed to include the export tax) because a substantial portion of the price received by the exporter is payable to the Government under this Act. An important point that rises in respect of this Act is the Federal Government's insistence that the tax still be collected despite the expiration of the authority to levy on April 1, 1974. Producers have been complying with this request although not required to do so by law. Many producers have probably been paying the tax in order to guarantee payment to them of compensation as crude oil importers.

The final piece of federal legislation is the Petroleum Administration Act which was introduced on April 2, 1974, by the Minister of Energy, Mines and Resources as Bill C-18. This Bill was referred to the Standing Committee on National Resources and Public Works, but did not receive Third Reading prior to the calling of the July 8 election.

Part I of this Bill sets out a charge of $\$ 4.20$ for each barrel of oil exported from Canada during the month of April 1974 and after April, the charge is to be revised but not to exceed $\$ 8.00$ per barrel. The charges are to be payable to the Government by the exporter.

The purpose of Part II of the Bill is to provide measures to achieve a uniform price for crude oil throughout Canada thereby not only protecting Canadian consumers from the instability of petroleum prices in the international market, but also achieving a balance in Canada between the interests of the producers and the consumers. This is intended to be achieved by establishing prices for crude oil extracted from a producer-province which are mutually acceptable to the federal government and the producer-province.

In the event agreement cannot be reached between the Federal Government and the producer-province under Part II, the provisions of Part III allow maximum prices to be established by the Federal Government for crude oil extracted from a producer-province.

The purpose of Part IV is to provide compensation to importers of crude oil who have maintained the level of prices for their products which are prescribed by the federal government under the authority given by this Part. 

to him.

Part V allows the Minister to require a variety of information to be supplied

To fully examine the effects of such legislation would require at least an amount of time equal to that allocated to the entire panel. Further, since many of the comments mentioned in respect of the Alberta Petroleum Marketing Act apply to this Bill as well, (subject of course to the jurisdictional problem) and because this Bill will hopefully retain its present status and not be reintroduced, further comment will not be made but will be left open for discussion. 